\title{
TIGER HUNTRESSES IN THE COMPANY RAJ: ENVIRONMENTALISM AND EXOTIC IMAGININGS OF WILDLIFE, 1830-45
}

VIJAYA RAMADAS MANDALA

\section{Abstract}

This article examines the history of huntswomen in colonial India in relation to nature, imperialism and forest fauna from 1830 to 1845 . In taking British women's hunting pursuits and environmental thinking as its focus, this study considers an activity often overlooked in assessments of women's contributions to colonial practices and dismissed almost entirely in accounts of imperial masculinity that take hunting as their subject matter. Moving beyond the framework of current historiography, this study intends to locate the presence of tiger huntresses in the 1830s and 1840s during the heyday of East India Company rule. The scope of this study also effectively contrasts the actions of British huntswomen in Britain and in India. Second, examining the Eden sisters in the spectacles of big game hunting during the Company Raj demonstrates the nature of British women's thinking towards Indian wildlife, which was also shaped by their political affiliations and family backgrounds in Britain, when they moved from Britain to India. Taking the subfields of the cultural and political ecology of India, this study illustrates how British women in this period articulated their exotic imaginings regarding Indian wildlife, such as tigers, elephants and wild pigs, that offers a fresh perspective to the reader. Hunting on the backs of elephants during the Company Raj also illuminates how the war functionalities of elephants that had existed in the eighteenth and early nineteenth centuries had faded away by the later period.

Keywords: hunting, women, India, wildlife, colonialism

\section{Introduction}

Historically, hunting as a kind of habitual cultural activity was practised by primitive and hunter-gatherer societies, as well as by members of ruling classes and privileged groups, in several regions across the world. Among the primitive societies, hunting was the chief subsistence activity. Among the ruling classes, since ancient times, 
it has been acknowledged 'as a pursuit that glorified masculinity ${ }^{1}$ and as a symbol of 'rule'. In England, from medieval times hunting became an exclusive pursuit of the gentry and nobility, excluding the ordinary people in the process, often labelling them as 'poachers'. But when Britons (a common term for the British in India) established their rule in colonies such as India, shikar or big game hunting also served them as an 'idiom of the rule' and a 'political practice', as well as a ruse by which to extend British control over Indian arable and marginal landscapes. ${ }^{3}$ In addition, big game hunting was transformed into 'sport' by colonisers, excluding ordinary Indians and pushing native shikaris (local hunters) and indigenous tribes into the roles of 'hunting assistants' and 'helpers' to the British by the late nineteenth century.

Hunting was described in detail in relation to the landscape, environment and wild fauna of the Indian empire and was elaborated into a conscious male-dominant colonialist discourse through the vast corpus of writing left by British imperial hunters, who were also officers, administrators, soldiers and planters. Accordingly, the British male hunter was described as the upholder of true masculine traits in the colonial world, when facing off against big game animals such as the tiger, leopard or the 'rogue' elephant, wild boar or rhinoceros, at the same time safeguarding the native populace against the onslaughts of these dangerous animals. Thus, it is unsurprising that such British men were instrumental in establishing big game hunting as a privileged colonial political practice, as well as in positioning such practice within the realm of 'sport' and British imperialism. Given this context, we might wonder, what about the role of British women in big game hunting in colonial India? Did women hunters exist during the Company Raj? The Company Raj refers to the period under British rule from 1757 to 1858, while this study refers to the period between 1830 and 1845 . Shikar, as used in this study, refers to big game hunting, or hunting for large sport in India. ${ }^{4}$ Other questions this study aims to explore include when and how did British women pick up the rifle to shoot ferocious animals such as the tiger or any other wild game? Is there a difference between women hunters and their hunting discourse in the Company period vis-á-vis the British Raj (i.e. colonial India, 1858-1947)? What is the underlying principle for British women participating in big hunts? What was the attitude of British women towards big game animals of the Raj, for example, the tiger and

1 Elahe Haschemi Yekani, The Privilege of Crisis: Narratives of Masculinities in Colonial and Postcolonial Literature, Photography and Film (Frankfurt and New York: Campus, 2011), 87.

2 Barbara Schrodt, 'Sports of the Byzantine Empire', Journal of Sport History 8, no. 3 (Winter 1981): 40-59; Charlotte Manning, Life in Ancient India (London: Smith \& Elder, 1856), 102.

3 See John William Kaye, The Life and Correspondence of Henry St. George Tucker, Late Accountant-General of Bengal, and Chairman of the East India Company (London: Richard Bentley, 1854), 43; C. E. Gouldsbury, Tiger Slayer by Order: Digby Davies, Late Bombay Police (London: Chapman and Hall, 1915), 28; A. E. Stewart, Tiger and Other Game - The Practical Experience of a Soldier Shikari in India (London: Longmans, Green \& Co., 1927), ix; J. T. Newall, Scottish Moors and Indian Jungles: Scenes of Sport in the Lews and India (London: Hurst and Blackett, 1889), 191.

4 www.collinsdictionary.com/dictionary/english/shikar, accessed 15 August 2019. 
the elephant, or any other forest fauna? To what extent did big game hunting in a colonial situation enable British women to disrupt gender hierarchies, even as they stood as active collaborators in justifying British imperialism? This study will analyse this set of questions with the help of some previously neglected texts by focusing on British huntswomen in colonial India as the principal subject of inquiry.

Before examining the subject of huntswomen in the Company Raj, this study proposes that hunting as an active pursuit was taken up by women earlier than historians have acknowledged. The hunting field for females laid emphasis on equestrian skills and a passion for the chase in England as early as 1787.5 A nineteenth-century woman writer even opined that 'A hunt is the most democratic of all conservative England's increasingly republican institutions', ${ }^{6}$ and there was no better thing than female participation in an arena that was chiefly dominated by males. Among women from privileged sections of society, it was not uncommon for them to ride a horse and lead the hounds to the hunting field. Some manuscripts from the fourteenth century then in the British Museum mention women in the open field, on horseback and on foot' and their 'following the game without masculine assistance'. ${ }^{7}$ Such examples can be found in later centuries too. The Tudor monarch Elizabeth I (Queen of England and Ireland, reigned 1558-1603) was fond of the equestrian chase, and in her lifetime was strongly disposed to long hours of hunting. Elizabeth believed that characteristics such as resilient 'energy' and 'skill' gained from hunting were also a regal representation of her authority in politics and government. ${ }^{8}$ Whenever season and climate permitted, she took an active interest in hunting parties, organised by a trusted nobleman, as diversion from courtly politics. ${ }^{9}$ For Elizabeth, the regular practice of hunting in the English countryside not only provided the quality of steadfastness in riding horses and managing the hounds, but also the reflection of grace and courage she had shown to the rural inhabitants. The underlying aspect here is how a Tudor queen did not shun the masculine trait of the equestrian chase, and instead carried out bucolic inspections and visited people under the guise of hunting. It demonstrates the political and strategic value of hunting among the Tudor ruling elite.

In the later eighteenth-century England, Emily Mary Cecil, Countess of Salisbury, maintained a pack of dwarf hounds at Hatfield for the purpose of hunting on her estate. She was generally believed to have been the first female Master of Hounds in England. ${ }^{10}$ On her home turf in Hertfordshire, Lady Salisbury held the office

5 Harriet Latham, 'Ladies in the Hunting-Field. 1787-1887', Peterson's Magazine (Philadelphia, PA) 92, no. 5 (1887): 415.

6 ibid., 418.

7 ibid., 415 .

8 ibid.

9 ibid., 416.

10 Erica Munkwitz, “"The Master is the Mistress”: Women and Fox Hunting as Sports Coaching in Britain', Sport in History 37, no. 4 (2017): 10, doi.org/10.1080/17460263.2016.1273846. 
of Master of the Hatfield Hunt from 1775 until 1819, when she was 70 years old. ${ }^{11}$ Lady Salisbury's hunting party was a 'theatrical spectacle'. Her servants dressed in 'sky-blue livery with black collars, lappels, [sic] and jockey caps', while Lady Salisbury always wore the richest and showiest of costumes. ${ }^{12}$ This decorative aspect of the equestrian chase did not diminish Lady Salisbury's display of physical strength, when in one of the hunts she took her horse to full speed in a group of 80 horsemen. ${ }^{13}$ The hunt lasted about two hours until the hounds captured their prey, when Lady Salisbury and another leading horseman were the only ones steering the hounds towards the successful completion of the hunt. ${ }^{14}$ For many years in the eighteenth century, a Yorkshire squire's daughter, Diana Draper, kept the dogs in chase in an orderly manner through her voice and vigilance, acting as second-in-command to her father, who was master of the hounds in his district. ${ }^{15}$ Such kind of privilege was accessible to only a few women in England, whereas the masculine peculiarity of 'equestrian skill' and 'horsemastership' further restricted the possibilities for women's participation in hunting.

Despite the above discussion shedding light on the history of women taking part in country hunts in England, it is an undeniable fact that a strong male lobby prevailed in Britain during the nineteenth century. This sporting lobby, represented by hunting clubs, became wary of female participation in equestrian pursuits. We need to be circumspect when stating that this kind of criticism of women's participation in the hunts gained prominence, when sporting journalism was at its peak during the high decades of British imperialism in the later part of the nineteenth century. However, the aforementioned analysis still leaves unanswered the question of big game hunting in colonial India in relation to British women. What about such women confronting dangerous, hitherto unencountered beasts such as tigers and other carnivores, and large (trained) animals such as elephants? British women's discourse on environmental imaginings of flora and fauna in the empire presents a different history, when we juxtapose this with hunting in Britain. The remaining paragraphs in the article will make an attempt to redress this gap.

A range of contemporary historical works on women hunters have explored the colonial period; in particular, they have shed light on the role of British women travelling to the colonies in Africa and Asia to participate in big game hunts. ${ }^{16}$

\footnotetext{
11 ibid., 10.

12 Harriet Latham, 'Ladies in the Hunting-Field. 1787-1887', 416.

13 ibid.

14 ibid.

15 ibid., 416-17.

16 See Mary A. Procida, 'Good Sports and Right Sorts: Guns, Gender, and Imperialism in British India', Journal of British Studies 40, no. 4 (2001): 454-88, doi.org/10.1086/386264; Callum McKenzie, "Sadly Neglected”Hunting and Gendered Identities: A Study in Gender Construction', International Journal of the History of Sport 22, no. 4 (2005): 545-62, doi.org/10.1080/09523360500122848; Mary A. Procida, Married to the Empire: Gender, Politics and Imperialism in India, 1883-1947 (Manchester: Manchester University Press, 2002).
} 
Kenneth Czech's With Rifle \& Petticoat: Women as Big Game Hunters, 1880-1940 examines women who made names for themselves through their hunting of a variety of big game animals around the world. Czech argues that during the nineteenth century, while women travellers witnessed or partly participated in hunts, they could not bring out their hunting adventures in print due to the difficulty of finding a publisher in a white, male-dominated sporting world. ${ }^{17}$ Second, the entering of British women into the realm of big game hunting in Africa and Asia, leaving behind their traditional gender responsibilities, was made possible by virtue of the "explorer and companion' roles that had become available to them when they accompanied their husbands, or through performing missionary work in the colonies. ${ }^{18}$ With the creation and growth of the discipline of natural history, many museums in Europe began to collect specimens and many European men who were sent to the colonies to collect them often took their wives along with them, who in the process picked up the gun both for their own defence and for hunting wild animals in their bid to subjugate forest people to their missionary cause. ${ }^{19}$ It is against this historical background that one must analyse the emergence of women's big game hunting mores in the latter half of the nineteenth and early twentieth centuries in India and Africa.

Mary A. Procida has argued that British women's involvement in taking up firearms shows 'the development of a new model of feminine behavior' in colonial situations, which is historically worth probing because it upsets 'many accepted ideas about gender in the empire'. ${ }^{20}$ Here, Procida refers to Clare Midgley's edited collection of essays Gender and Imperialism, which made a scholarly attempt to 'introduc[e] gender as an analytical concept into the study of empire'-a critical omission by mainstream historians. ${ }^{21}$ When placed in this methodological framework, British women's use of firearms should be seen as a direct engagement with empire, one that exhibited their support for the imperial cause while integrating themselves into the symbolic and practical politics of the Raj'. ${ }^{22}$

Callum McKenzie's work likewise poses the question of the role of women and where they stand in the male-dominated world of hunting, whether in Britain or in the colonies. ${ }^{23}$ Throughout the nineteenth and early twentieth centuries, he notes, shooting wildlife was deemed to be a necessary component and a demonstration of

17 Kenneth Czech, With Rifle \& Petticoat: Women as Big Game Hunters, 1880-1940 (Lanham, MD: Derrydale Press, 2002), $x$.

18 ibid.

19 ibid., $x-x i$.

20 Procida, 'Good Sports and Right Sorts', 455.

21 ibid., 458; also see Clare Midgley's introduction 'Gender and Imperialism: Mapping the Connections', in Gender and Imperialism, ed. Clare Midgley (Manchester: Manchester University Press, 1998), 1, doi.org/10.7765/ MSI/9781526119681.01.

22 Procida, 'Good Sports and Right Sorts', 488.

23 McKenzie, “'Sadly Neglected”', 548. 
masculinity. McKenzie in this context refers to the British male-dominated worldview of big game hunting, in which dangerous pursuits such as 'alligator shooting' and other 'unfeminine practices' should be undertaken by the men of sporting fraternity, thus undermining women in the process. ${ }^{24}$ The well-known sporting magazine of this period The Field even questioned 'whether women should be allowed to "draw blood" from sentient life'. ${ }^{25}$ The foremost opponents to women's entry into the sport of hunting were many men. Consequently, many nascent women hunters were given a hard time and vilified by influential male society in Victorian Britain. ${ }^{26}$ For males and the dominant sporting press in Britain, the question was in fact one of 'appropriate social training for adulthood', which they considered was a restricted right and privilege available only to boys. ${ }^{27}$ In this context, Anne M. Windholz's study 'An Emigrant and a Gentleman' elucidates the reasons an increasing number of British males took up imperial service: 'young men who came of age in England at the end of the nineteenth century did so as the very nature of masculinity was being contested in social, economic, and sexual arenas. ${ }^{28}$ Thus, it is understandable that British males took up lucrative colonial opportunities, as well as big game hunting as a 'rite of passage', a symbol of imperial power due to its popularisation in Britain and the empire. But what about women and their response to contesting a field so dominated by British males in the colonial world, as well as at home?

In this context, McKenzie's study offers the example of a colonial huntswoman, Isabel Savory (1869-1967?), and her repeated call for freedom for 'Diana' to encourage women's active participation in big game hunts. ${ }^{29}$ Savory's writing characterised 'a departure from the male-dominated hunting literature', as she challenged the stereotypical hegemonic and masculine hunting notions that appeared 'in the works of Robert Ballantyne, Rudyard Kipling, George Henty and their ilk' '. ${ }^{30}$ Contrary to the male-dominated hunting culture that was characterised by the 'blood and gore' aspect of killing big game, Savory's hunting exploits in India and Africa emphasised shooting wild animals effectively in 'a "selective" rather than "non-selective" sporting order. ${ }^{31}$

The above discussion establishes how hunting was considered a rite of passage for British males in the colonial order of empire, but begs a reconsideration of how the image of a gun in the hand represented the role of British women's active engagement as defenders of imperialism as well as their integration into the symbolic and practical

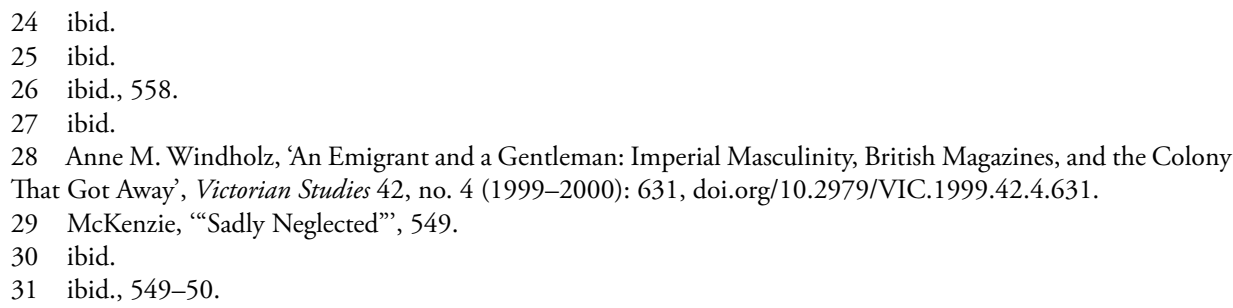


politics of the Raj. I aim to examine this premise in the context of environment and empire by illustrating how hunting by British women for big game took place much earlier than the existing secondary works credit — that is, that it took place during the East India Company period. This study suggests that British women's access to the big game world, which tied them to the symbolic politics of the Raj, was achieved with the help of native servants, although this was rarely acknowledged. The Eden sisters' colonial imaginings of Indian wildlife also embodied an aspect of the state-making process on the fringes of empire. Besides, the huntswomen's thinking towards the hunted fauna differed widely from male-dominated big game hunting mores - an important historical development in relation to shikar in India that both Procida's and McKenzie's writings have overlooked.

\section{Huntswomen in the East India Company period}

Taking the memoirs of Emily and Fanny Eden as evidence, the present study suggests that British women in India were notable huntresses as early as the 1830s. Emily Eden (1797-1869) was the sister of the earl of Auckland, the GovernorGeneral of India between 1836 and $1842 .{ }^{32}$ Like many members of British families, she accompanied her brother to India in 1836, spent many years in the country and wrote of her experiences, which were published as Letters from India (1872), in which she recounted her participation in many tiger-shooting expeditions. Both the Eden sisters' communications in the form of letters to their family in England were replete with descriptions of India's big game animals and lavish hunting expeditions that took place between 1836 and $1842 .{ }^{33}$

Before his appointment as Governor-General of India in 1835, George Eden, first Earl of Lord Auckland, already had a considerable political reputation as President of the Board of Trade, and after completion of his Governor-Generalship he took up the post of First Lord of the Admiralty. ${ }^{34}$ The Edens were one of the great Whig families (supporters of the seventeenth- and eighteenth-century British political movement that supported political and social change). They were also friends of Lord Melbourne, who after assuming the office of prime minister in 1835 had 'cancelled the Tory appointment in India and offered the Governor-Generalship to Lord Auckland'. ${ }^{35}$ Auckland's appointment to India proved to be a calamity for the Eden sisters, as it disrupted their pleasant and stimulating life in England. Besides, the Edens 'were part of a large, close-knit family of sisters and brothers, nieces and

32 P. J. Marshall, 'Eden, George, Earl of Auckland (1784-1849), Governor-General of India' in Eden, George, Earl of Auckland (1784-1849), Oxford Dictionary of National Biography (Oxford: Oxford University Press, 2004).

33 Emily Eden, Letters from India ... Edited by Her Niece, vol. 1 (London: Richard Bentley and Son, 1872), 177, 275.

34 Janet Dunbar, Golden Interlude - The Edens in India 1836-1842 (Boston, MA and Cambridge: Houghton Mifflin Company and the Riverside Press, 1956), ix.

35 ibid., ix. 
nephews, cousins and near connections, with whom they kept in touch by visits and regular correspondence' ${ }^{36}$ It was due to their strong attachment to their brother that the Eden sisters accompanied him to India. This discussion of family ties and ties to the empire is pertinent here as it shows that it was the highly privileged background of the Eden sisters that enabled them to embrace and participate in big game hunting adventures, which were otherwise denied to women in the nineteenth century. In the following pages, we shall see how hunting came to be a rite of passage for British women with political backgrounds.

The lived experience of Emily and Fanny Eden in India demonstrates that, much as with British men, the early phase of the colonial period not only provided opportunities for them to try new experiences but also shaped two different kinds of mindsets. This duality is present in their understanding of big game scenes in India. In particular, Fanny Eden's role as an eyewitness and participant in big game hunts in India reveals 'her sense of adventure and quick acceptance of the odd, unexpected happenings of life' ${ }^{37}$ But this attitude of openness did not come without initial fear or bewilderment for Fanny Eden. On the other hand, while Emily Eden did not hunt tigers, she encouraged her sister to exploit all the hunting opportunities available to her in her capacity as sister of the Governor-General of India.

In one of her letters to her family in England, Emily reports that Fanny was planning a tiger shoot, which she thought sounded 'rather awful', but she advocated it for the prospect it afforded of living in tents in wild jungles, travelling on elephants and seeing wild rhinoceroses, of doing 'all the things that ought to be done in India' and for getting a good break away from humdrum life in Calcutta. ${ }^{38}$ As Fanny too points out, while her sister Emily 'positively declares that nothing shall ever make her go to a tiger-hunt', she considered it 'strange and cowardly' of Fanny if she would have neglected such an opportunity. ${ }^{39}$ One of Fanny Eden's travel journals describes an account of a tiger shooting trip to the Rajmahal Hills in the Bengal Presidency, which she joined 'armed with a sketchbook instead of a gun': ${ }^{40}$

While admitting that man-eating tigers had to be destroyed, she [Fanny Eden] found more pleasure in riding on her elephant through the rose-covered jungles which hid the great beasts. She passed through villages where no white woman had ever been before, seeing primitive [tribal] India through the eyes of a friendly, sympathetic memsahib, completely different from the stock type [of other British women] of those days. ${ }^{41}$

36 ibid.

37 ibid., xi.

38 Eden, Letters from India, 275-6.

39 ibid., 280.

40 Dunbar, Golden Interlude, xi.

41 ibid., xi. 
Fanny Eden's letters also inform the reader about her preparation for a shikar adventure near the hills, 140 miles from Calcutta, and that 'the unsophisticated population of those hills is entirely composed of tigers, rhinoceroses, wild buffaloes, and now and then, a herd of wild hogs ${ }^{42}$ She writes:

There, I'm going to live for three weeks in a tent. I shall travel the first fifty miles in a palanquin, ${ }^{43}$ and then I shall march. It takes a full week to travel a hundred miles in that manner ... as our beds, armchairs, tables, and clothes all travel on the heads of human beings [Indian servants]. ${ }^{44}$

While 'secretly alarmed at the tiger-shooting part of the trip' on account of frightening stories related to the misdeeds of tigers and jungle fever, Fanny Eden was assured of a refreshing journey for a few weeks in the hills to catch-up and draw the jungle scenery. ${ }^{45}$ Writing to a friend (Eleanor Grosvenor) in England, Fanny Eden expressed her apprehension on the upcoming hunting trip: '(the shikar expedition) will eventually conduct me either to the bottom of a tiger's throat or the top of a rhinoceros' horn'. ${ }^{46}$ Emily Eden wrote to Theresa Lister in 1837 that Fanny would be going on a tiger shooting expedition with their family friend, William Osborne, in the Rajmahal Hills:

[There] they would be joining a Mr. and Mrs. Cockerell, who made one of these hunting trips every year. Mrs. Cockerell was a sharp little woman, almost pretty, and very ill-natured or so Emily had heard. But Fanny would not see too much of her, for Mrs. Cockerell was a keen tiger-huntress, and so would be out on her elephant with the men [and overseeing tiger-hunting expeditions]. ${ }^{47}$

While Emily was insistent that her sister pursue the tiger hunt, Fanny considered such hunts troubling, reiterating that 'William won't hear a reason $[s i c]$ as to the horrible dangers he is going to take me into'. ${ }^{48}$ Fanny blamed Theresa Cockerell (1809-53, mentioned above) and another British woman who regularly would ride on the backs of elephants, and go out tiger-hunting every day, and in the process endangering their lives. She protests that 'they talk of the excitement of the tiger's spring, and the excellent day it was when they saw eight [tigers] killed'. ${ }^{49}$ While Fanny did not indulge in tiger shooting, during the period of her residence in India she was a very active participant in several tiger hunts, riding on elephant back. She continued to observe Mrs Cockerell's hunting prowess along with that of the British huntsmen, describing many of their adventures, which offered them the thrill of

42 ibid., 58.

43 In India and the East Asian countries, a covered litter for one passenger, consisting of a large box carried on two horizontal poles by four or six bearers.

44 Dunbar, Golden Interlude, 58.

45 ibid., 59.

46 ibid,. 58-59.

47 ibid., 58

48 ibid., 59.

49 ibid., 59. 
the hunt, as though they were almost 'in the very jaws of the tigers'.$^{50}$ On another occasion in a safe part of the country, Mrs Cockerell had shot a tiger and returned home 'fresher and better dressed than ever, quite delighted and only wishing' that the tiger had shown more fight. ${ }^{51}$ The daily letters of Fanny Eden reveal the abundance of the tiger population across the Bengal Presidency, many of them classified maneaters. During the East India Company rule in India, the act of hunting was not one that its participants seemed to regard as needing justification, although some elevated it to the status of a science by donating specimens to museums. But it was unsurprising that at an official level the Company Government found it necessary to destroy them as part of the 'vermin eradication' program. ${ }^{52}$

Fanny refers to her hunting party going in pursuit of three 'real good tigers', and Mrs Cockerell proclaimed such a goal as 'worth going after' since tigers had eaten many of the nearby villagers, thereby alluding to the presence of the man-eater carnivore problem in the region. ${ }^{53}$ The above instances show the presence of tiger huntresses during the Company period, even as the Eden sisters were settling down in India. Thus, the disruption of gender roles was not unique to just the women of the later Raj, as the writings of Procida and other scholars have implied. But such instances could already be witnessed in the early part of the nineteenth century, when many British women had gone in pursuit of tigers- the most favoured pastime for early Britons in India. ${ }^{54}$ The letters written by the Eden sisters in India also elucidate how observation of the Indian environment derived from the imagination of British women and how its meaning was transmitted by reinforcing Britons' view of empire as an enchanting and exotic place. British women's interaction with the political and cultural ecology of India also lent them a certain legitimacy with which to maintain coherence and support for the colonisation and control of fringe and arable landscapes.

Fanny Eden, along with other British huntresses of this period such as Mrs Cockerell, enjoyed a key political endorsement relating to the epicentre of imperial power in India (i.e. tiger hunting). The Eden sisters' writings and experience in the hunting field also transcend the intersection of class, race, imperial power and gender privilege as early as the 1830s. Besides, they underscore their textual engagement and growing interest in the business of empire, as witnesses to colonial historyin-the-making, class and racial identity (of Englishness) in India as part of British

50 ibid., 69.

51 ibid., 73

52 Bengal Rev (LP) 10 Sept 1828, draft 472/1827-28, 243-45. IOR/E/4/723. British Library (BL); Bombay Pol. 1 Jun 1842, Draft 303/1842, 663-89. IOR/E/4/1070. BL; also see John B. Seely, The Wonders of Elora (London, G. and W. B. Whittaker, 1824), 376-7; Jubbulpore Roads, Mirzapore, Measures for Destruction of Tigers (1834-1837). OR/Z/E/4/14/R495. BL; Gratuities to Families of Victims Killed by Tigers and Wild Beasts, 345, 645. IOR/Z/E/4/16/W177 and IOR/E/4/760. BL.

53 Dunbar, Golden Interlude, 74.

54 ibid., 58, 59, 61, 95. 
colonial authority. The liability and blame attached to hunting whenever a wild animal was killed, but equally a desire to appreciate the aesthetics of Indian cultural ecology, also offer a 'representational equilibrium between rhetorical detachment and colonial involvement'. ${ }^{55}$ Angelia Poon, while observing such historical interplay as an example of colonialism's politics of performance, points out that the 'link between seeing and knowing, long a crucial feature of the Western metaphysical tradition of cognition, underpins colonial epistemology as well'. ${ }^{56}$ In the case of Fanny Eden, the dynamics of seeing and knowing as a thoughtful bystander and participant, as someone from a colonial power, extends an important dimension in the colonisers' venture in creating the colonial knowledge of animal realms in relation to the Indian environment.

Her years of experience and familiarity with the tiger hunt made Fanny Eden develop an unusual liking for elephants. According to her, these animals possessed 'intelligence' and 'resourcefulness', but 'she regretfully observed that she could not extend [this admiration] to tigers, alligators or snakes' ${ }^{57}$ It is noteworthy that British women were no exception when it came to holding the belief that predatory animals such as tigers, alligators or wild pigs needed to be vanquished, while elephants were friends for their invaluable use to the British in tiger shoots and military expeditions during this period. From a hunting camp, Fanny Eden writes:

We are staying here [in the jungle], excessively baffled by the tigers. They saw one large one yesterday afternoon, but in such thick jungle, the elephants could not make their way after him ... There was something grand in the way all the elephants set off stamping and screaming, and follow[ed] up the traces of a tiger in jungles where it seems a sin and a shame to fancy a tiger could be [hiding in] soft grass, with clumps of rose bushes white with roses, and thousands of butterflies hovering over them. ${ }^{58}$

Elephants are the best beasts to see much of-I cannot say the respect I have for them. Though not naturally witty I suspect they have much more common-sense than we [humans] have. ${ }^{59}$

This depiction of the character of elephants and tigers in the case of Fanny Eden's experience in the forest is noteworthy. She was inadvertently reflecting broader British attitudes towards India's two magnificent beasts, as enshrined in the colonial program of hunting and preservation-an aspect of this program that continued to

55 Angelia Poon, Enacting Englishness in the Victorian Period: Colonialism and the Politics of Performance (London: Routledge, 2008), 75.

56 ibid., 77.

57 Dunbar, Golden Interlude, 48.

58 ibid., 75 .

59 ibid., 75. 
mirror the official mindset of the British Raj. ${ }^{60}$ In the above-mentioned occasion, Fanny Eden was inferring that while to a naturalist's eye the forests of India were sublime and striking with their variegated flowers and non-predatory wildlife, they also had 'brute' and 'dangerous' animals such as tigers lurking behind soft grass and rose bushes. The implication here is that the natural environment of India, despite its external aesthetic value, also provided a safe haven to dangerous beasts of prey. To extend John Miller's claim to the present study, the modern environmentalism reckoned through Fanny Eden's ecological sensibilities illustrates her attempt to colonise 'landscape with beauty and mystery, with the kind of otherness that makes wilderness vital to romance and which is far harder imagined in intensely managed, charted and cultivated lands' ${ }^{61}{ }^{1}$ In a way, for the British in India, the romantic sojourn happened in the real wilderness with its thriving biodiversity on the peripheries of empire. Accordingly, this study contends that Fanny Eden's experience offered the nostalgia of imperial romance (i.e., the idea of the exotic and the unknown) for British women in the early nineteenth century, which was not found at home in Britain.

As Pramod K. Nayar, too, illustrates, the English sportswoman's hunting expedition 'narrates the Indian wilds through the aesthetic of the luxuriant, an aesthetic that combines beauty with danger'. ${ }^{62}$ Hunting encounters with wild animals meanwhile were portrayed as 'an aesthetic risk'. ${ }^{63}$ This aspect explains the background that despite the risky pursuit of hunting, the forest environment offered a healthful recreation; even as the flora presented a sublime view, the wild predators inhabiting these jungles posed a danger or challenged the prowess of a hunter or a huntress. It also raises the question of extending British control over forest interiors. This kind of early construction in colonial imaginings of the Indian wilderness changed after the 1857 revolt. The luxuriant forest then became the object of the colonial project of empowerment, conquest and control. This would attest to the fact that the earliest aesthetic picturesque of Indian forests eventually was made into a testing ground to implement key imperial ideologies in India. One sees this shift taking place as the British gained interest in the acquisition and stewardship of territory, conservation and ecological policies from the 1860s onwards. Such a transition became enshrined in policy with the establishment of Indian Forest Service in $1864 .{ }^{64}$ This article argues that colonial knowledge and power relationships were applied to wild animals

60 Mahesh Rangarajan, 'The Raj and the Natural World: The War against "Dangerous Beasts" in Colonial India', Studies in History 14 (1998): 265-99, doi.org/10.1177/025764309801400206; Vijaya Ramadas Mandala, 'The Raj and the Paradoxes of Wildlife Conservation: British Attitudes and Expediencies', Historical Journal 58, no.1 (2015): 75-110, doi.org/10.1017/S0018246X14000259.

61 John Miller, Empire and the Animal Body: Violence, Identity and Ecology in Victorian Adventure Fiction (London: Anthem Press, 2014), 30.

62 Pramod K. Nayar, English Writing and India, 1600-1920: Colonizing Aesthetics (London: Routledge, 2008), 6, doi.org/10.4324/9780203931004.

63 Nayar, English Writing and India, 6.

64 ibid.; also see Benjamin Weil, 'Conservation, Exploitation, and Cultural Change in the Indian Forest Service, 1875-1927’, Environmental History 11, no. 2 (2006): 319-43, doi.org/10.1093/envhis/11.2.319. 
and their environments in the narratives of the Eden sisters and, later, other British sportswomen in the later nineteenth and early twentieth centuries. These accounts demonstrate that the colonial construction of India, which granted particular roles for imperial governance and political authority, likewise was put in place by their construction of Indian forest territories through an aesthetic, ecological mode. ${ }^{65}$

Another feature of the big game hunting scene that Fanny Eden witnessed was the trumpeting and warlike nature of the Company Raj's shikari elephants whenever they were marched into the forest in search of hunting opportunities. A British account of hunting scenes in India prior to 1833 , too, reports on the suitability of employing such elephants in big game shoots:

No conveyance can be more delightful, or better suited to the country; from the altitude gained by mounting a tall elephant, we [i.e. the British hunting party] command a vast extent of prospect, and there is a feeling of perfect security, arising from the extraordinary sagacity of the animal, which in the wild passages of these uncleared jungles, is very satisfactory. ${ }^{66}$

This illustrates how the British found elephants the best and safest method of transportation in the jungle interiors. Such hunting expeditions were accompanied by a number of chuprasies (peons or servants) and chobedars (masters of ceremonies) wearing a variety of ornamental clothing (white clothes and red turbans), and carrying swords and silver maces. ${ }^{67}$ But an interesting aspect of the above discussion is its reference to 'uncleared jungles', which accentuates the implication that the Indian marginal landscapes were still unscathed by colonial encroachment, even though hunting expeditions were taking place for pleasure.

The skill of Britons was not just that of men and women who brought down tigers, rhinoceroses, alligators or wild pigs with their guns, but that of shikari elephants of the Company Raj, which would retaliate with ferocity and sagacity, especially when they were charged by any predatory animals. ${ }^{68}$ As Fanny Eden writes:

The gentlemen have with them each six rifles in their [elephant] howdahs and shoot at all the innocent wild beasts they meet. Just as I was [looking] upon the exceeding beauty of one rose bush, a great wild hog rushed out of it and charged the elephant Mrs. C[ockerell]. and I were upon. The instant after, it had five balls through it and then I settled that I had no taste for the shooting part of the expedition, and shall confine my genius to the picturesque, and there is more than enough space for it here. ${ }^{69}$

65 See Alan Gardner, Rifle and Spear with the Rajpoots: Being the Narrative of a Winter's Travel and Sport in Northern India (London: Chatto and Windus, 1895), doi.org/10.5962/bhl.title.17641; Isabel Savory, A Sportswoman in India-Personal Adventures and Experiences of Travel in Known and Unknown India (London: Hutchinson, 1900), doi.org/10.5962/bhl.title.33466; Dunbar, Golden Interlude.

66 'High Life in the East. No. II. Hawking', The Court Journal: Gazette of the Fashionable World, 11 May 1833, 315.

67 ibid.

68 Dunbar, Golden Interlude, 70-3.

69 ibid., 70. 
Referring to one of the hog-hunting episodes, Fanny Eden writes:

I thought that hog's was a shocking case of murder ... The elephants set to work to trample it [the wild hog] to death, and when at last it was dead, they insisted upon my looking at it. It seemed to be such a fine strong beast, so exactly fitted to its own jungles. I do not see our [Britons'] right to take our love of destruction there. ${ }^{70}$

This observation of a 'live hunting expedition' is interesting also as a first-hand account of 'what must have been a unique experience for a high-bred Whig lady' such as Fanny Eden. ${ }^{71}$ Her criticism of the destruction of Indian wildlife by her fellow Britons was clearly shown in this instance of hog-hunting, which she believed to be no less than a 'shocking case of murder' ${ }^{72}$ She was equally surprised at how Indian elephants were trained in the art of hunting, as their actions of trampling wild hogs or fiercely retaliating against rhinoceroses would seem to suggest. ${ }^{73}$ She further writes, 'if I were given to shooting, I would shoot deer and peacocks without having fifty elephants to help me', protesting against shikari elephants making such a grand show in the forest. ${ }^{74}$ It is pertinent to note here that the instances of shikari elephants discovering the whereabouts of tigers in the shrubs of the jungle or charging back at any intimidating wild animal are confined to the East India Company period. Elephants in the later period were not trained to carry out such acts.

Thomas R. Trautmann's deliberation on the institution of the war elephant in the context of environmental history is germane here. ${ }^{75}$ His study suggests that unlike in other parts of the world, such as China and Africa, elephants in India took part in some of the greatest wars of antiquity - a history that spans more than 3,000 years, which went beyond India onwards to Persia, and then to Europe. Since elephants eat such massive quantities of food, it was unprofitable to raise or maintain them. By introducing the native knowledge system of domestication, the Indian kings captured wild adults and trained them, using trained elephants for official purposes, inspecting the provinces, rituals, royal hunts and in warfare. The rulers of India found an intelligent strategy to sustain wild elephant populations. The 'elephant forests' were instituted along with the invention of the war elephant. They ensured the protection of wild elephants from hunters and poachers, and 'elephant forests' were prevented from being cut down. Studying the underpinning of human-elephant relations and its agency, Trautmann persuasively demonstrates the structure of India's environmental history and the reasons for the presence of wild elephants in its forests over the past two millennia. Safeguarding wild elephant populations with domesticated and trained ones was a political practice with regal sanction, and was

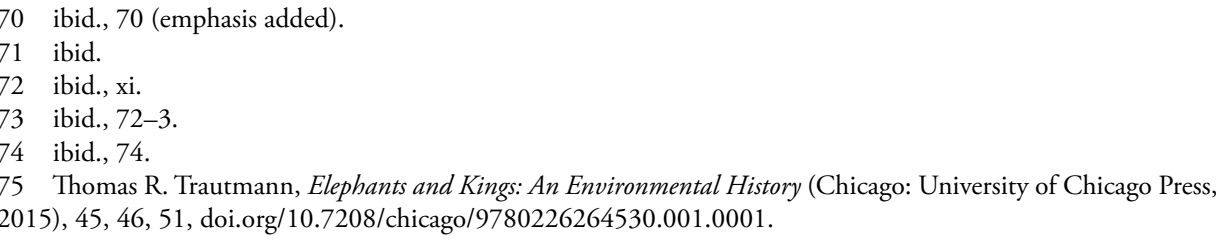


continued even up to the arrival of the British. It is with this backdrop that Britons in India continued to exploit elephants in hunts as well as for various other tasks, thus consciously deriving their ruling licence from pre-colonial Indian traditions. John M. Kistler observes that 'the training of war elephants probably parallels the training of pachyderms for tiger hunting, ${ }^{76}$ as is evinced by the case of the Company Raj's elephants, discussed above.

What is noteworthy, then, is Fanny Eden's figuring out of the role of Indian elephants in shikar from a British woman's point of view. The nature of violence from an animal (elephant) meted out to another forest animal (wild hog) also underscores the predatory care of the Company Raj and its adaptation to the physical environment of India. Fanny Eden's account of shikari elephants also emphasises, to borrow from Sujit Sivasundaram, an anthropomorphic gaze in observing an animal's character and temperament, and an anthropomorphic bent in relation to Britons' understanding of India's flora and fauna. ${ }^{77}$ This manifestation of new and hybrid forms of information was crucial to making colonial knowledge in relation to the ecosystems of the Indian subcontinent. Besides, the negotiation between British huntswomen (as illustrated by Fanny Eden) and natural knowledge was unleashed in the peripheries of empire and extended to animal realms (i.e. non-human spaces).

While Fanny Eden did not altogether indulge in big game sports, she nonetheless participated in such pursuits along with Mrs Cockerell—whose involvement also attests to the fact that many British women in the Company Raj were notable shooters of big game animals in terms of their practical experience. However, they did not record their hunting recollections, or could not publish them as the Eden sisters did, even as their role as tiger huntresses would seemingly suggest they could have done so. One possible reason for this lapse was that publishers both in England and in India during this period believed that hunting was a male privilege in the public arena, and consequently was not sanctioned by society for women. Conversely, one notable dimension of British women across various colonies was the evocation of the idea of 'British subjecthood', which served as 'an imperial form of belonging, symbolically and culturally tying the disparate branches of the colonial empire to the (British) metropole. ${ }^{78}$ This 'subjecthood' in the Eden sisters' writings, though not spelled out literally, also encapsulates Anglo-Saxon women's political space and temporality in the cultural geography of India, fashioned by their firsttime experience in Indian wilderness and its vivid flora and fauna, which reinforced their encounters with the notion of the exotic imperial 'Other'.

76 John M. Kistler, War Elephants (Lincoln, NE: University of Nebraska Press, 2007), 11

77 Sujit Sivasundaram, 'Trading Knowledge: The East India Company's Elephants in India and Britain', Historical Journal 48, no.1 (2005): 30, doi.org/10.1017/S0018246X04004212.

78 Matthew P. Llewellyn, "For a "United" Kingdom and a "Greater" Britain: the British Olympic Association and the limitations and contestations of "Britishness", in The British World and the Five Rings: Essays in British Imperialism and the Modern Olympic Movement, ed. Erik Nielsen and Matthew Llewellyn (London: Routledge, 2016), 18, doi.org/10.1080/17430437.2014.990687. 


\section{Conclusion}

This study has attempted to situate women's hunting activities as early as in the days of the Company Raj through consideration of the Eden sisters' accounts of tiger hunts. It should, however, be noted that continuities between East India Company rule and the later Raj continued in the form of participation in tiger hunts by the upper echelons of British women, often as wives of viceroys, governors-general and British royalty. For example, vicereines such as Lady Curzon and Lady Minto participated in such colonial hunts, which were more 'staged' and less dangerous. For example, in 1907, Lord and Lady Minto joined the Maharajah of Cooch Behar in the Bengal Presidency for a shoot, where they bagged three tigers in the morning and four in the afternoon in a single day. ${ }^{79}$ Minto stayed for a full one week and his wife had the opportunity to shoot a tiger. ${ }^{80}$ These hunting activities thus accentuated the colonisers' image in the empire by putting their energy and showmanship into sport befitting the rulers. John MacKenzie terms it 'female participation in imperialism', ${ }^{81}$ where shikar practices were remoulded and refined by the British soon after the consolidation of their political rule across India.

To recapitulate, hunting in the Company Raj offered a combination of experiences to British men and women and was available as an activity to members of the politically privileged sections of society. By creating a pan-Indian ruling identity (Anglo-Indian or the British in India), this privileged group actively participated in tiger shooting expeditions, chasing wild hogs and rhinoceroses, and even shooting alligators from the backs of shikari elephants. Our study has demonstrated that British women in the Company period hunted tigers and other dangerous predatory animals. However, it is evident that they did not articulate, or invent, the language of hunting as 'sport' or the semantics of 'sportswomanship'-literary symbolism in relation to actual practices - an idea that emerged only during the latter half of the nineteenth and early twentieth centuries. Likewise, there were very limited avenues for the publication of works on hunting by British sportswomen, for the reasons mentioned above. Despite these limitations, the writings of the Eden sisters during the early nineteenth century would illustrate how Britons followed the practice of big game hunting and tiger shooting on the backs of elephants. They indulged in this practice of chasing wild animals so as to invoke ecological authority over Indian marginal landscapes by mimicking the political norms and recreational gatherings of the Indian ruling elite. Hunting provided British women with a metonym for ecological empire-building and opportunities to admire the exotic beauty in the wilderness of India.

79 Nripendra Narayana Bhupa, Maharajah of Cooch Behar, Thirty Seven Years of Big Game Shooting in Cooch Behar, The Duas and Assam (Bombay: The Times Press, 1906), 411-13.

80 ibid., 414.

81 See general introduction by John MacKenzie in Procida, Married to the Empire, viii. 
This study has illustrated some of the most evocative examples of hunting, gender and imperialism in relation to environmental history. Participation in the equestrian chase by British women in England did not create veritable battles like those of tiger huntresses bumping into big game in colonial India. The connection between the animals of the Raj, hunting and colonialism also signified the latitude of British control over forest interiors and the symbolic conquering of the Indian environment, in which some British women had taken an active part since the days of East India Company rule. Such traditional hunting practices thenceforth continued to form a part of later British appreciation of Indian big game hunting mores. 
This text is taken from International Review of Environmental History, Volume 5, Issue 2, 2019, edited by James Beattie, published 2019 by ANU Press, The Australian National University, Canberra, Australia.

doi.org/10.22459/IREH.05.02.2019.04 